\title{
Cross-cultural adaptation of the Transition Readiness Assessment Questionnaire to Argentinian Spanish
}

\author{
Carmen L. De Cunto, M.D. ${ }^{a}$, Alfredo Eymann, M.D. ${ }^{b}$, María de los Ángeles Britos, M.D. ${ }^{a}$, \\ Florencia González, M.D. ${ }^{c}$, Mariana Roizen, M.D. ${ }^{d}$, \\ María de las Mercedes Rodríguez Celin, M.D. ${ }^{e}$ and Enrique Soriano Guppy, M.D. ${ }^{f}$
}

a. Division of Pediatric Rheumatology, Division of Clinical Pediatrics, Department of Pediatrics of Hospital Italiano de Buenos Aires.

b. División of Clinical Pediatrics, Department of Pediatrics of Hospital Italiano de Buenos Aires.

c. Research fellow in the Departments of Bone Marrow Transplant and Growth and Development of Hospital Nacional de Pediatría Juan P. Garrahan.

d. Department of Bone Marrow Transplant of Hospital Nacional de Pediatría Juan P. Garrahan.

e. Department of Growth and Development of Hospital Nacional de Pediatría Juan P. Garrahan.

f. Division of Rheumatology, Department of Clinical Medicine of Hospital Italiano de Buenos Aires.

E-mail address:

Carmen De Cunto, M.D.: carmen.decunto@ hospitalitaliano.org.ar.

Funding:

None.

Conflict of interest: None.

Received: 6-7-2016 Accepted: 9-15-2016

\begin{abstract}
In Argentina, there was not an adapted and validated instrument to evaluate readiness for the transition to adult health care. The purpose of this study was to describe the process of cross-cultural adaptation of the Transition Readiness Assessment Questionnaire 5.0 to Argentinian Spanish.

The authors of the instrument were contacted to this effect. Stage 1: two translators performed the translation toSpanish. Stage 2: based on these two versions, version 1 was agreed upon. Stage 3: two back-translations were performed. Stages 4 and 5: both back-translated versions were compared, and the Spanish version was adapted to ensure correspondence with the original. Subheads were added in each domain, and version 2 was obtained. Stage 6: the questionnaire was field tested toensure the cultural adequacy of the vocabulary, thus obtaining version 3 . In the last stage (stage 7), the instrument was tested in two hospitals. Finally, the cross-cultural adaptation of the Transition Readiness Assessment Questionnaire 5.0 for the Argentinian population was obtained.

Key words: transition to adult health care, surveys and questionnaires, chronic diseases, adolescence, cross-cultural comparison.
\end{abstract}

http:/ /dx.doi.org/10.5546/aap.2017.eng.181

To cite: De Cunto CL, Eymann A, Britos MÁ, et al. Cross-cultural adaptation of the Transition Readiness Assessment Questionnaire to Argentinian Spanish. Arch Argent Pediatr 2017;115(2):181-187.

\section{INTRODUCTION}

The shift of patients with chronic conditions from pediatric to adult health care is a complex process that entails difficulties for all actors involved. Transfer is defined as the single act of transferring the patient from one health care facility to another. Transition is conceived as a dynamic, complex, planned process, which includes the transfer itself.

Given the complexity of different chronic diseases, the transition process requires adolescents to acquire skills aimed at increasing their autonomy in relation to self-care, turning them into responsible and trained individuals capable of taking care of themselves and, at the same time, families and health care providers should be ready to accompany these patients through the process depending on each patient's individual health status. ${ }^{1}$

In other countries, several instruments have been developed in the form of a questionnaire to assess the skills acquired by patients in their transition to adulthood. ${ }^{2}$ Questionnaires available at present include those that explore these general aspects (generic questionnaires), and some targeted at a group of patients with specific conditions (specific questionnaires).

In Argentina, to date, there was not a validated instrument targeted at our population.

Among the available generic questionnaires, we identified the Transition Readiness Assessment Questionnaire (TRAQ), which was first developed at the Florida State College at Jacksonville, USA, based on the analysis of several lists of questions and questionnaires used by different transition working groups, but which had not been validated..$^{3,4}$ The selected questions assessed knowledge, attitudes, and behaviors related to different domains.

The TRAQ authors modified the questions to account for patient's skills instead of knowledge. Response options focused on the "transtheoretical model of change" because authors considered that this model corresponded to the skill acquisition development process 
among adolescents. The model comprises five stages: precontemplation, contemplation, preparation, action, and maintenance. The resulting questionnaire assesses patients' skills that are relevant to establish their preparation to shift to the adult health care system, and has demonstrated adequate psychometric properties., ${ }^{3,4}$

Publications provide sufficient evidence indicating that it is easier to validate an already available and useful instrument (if any) rather than developing a new one, and is also helpful to compare different populations. ${ }^{6}$

However, in order to use a questionnaire developed in a different culture, a cross-cultural adaptation is necessary. The purpose of this process is to ensure that the new questionnaire is conceptually equivalent to the original version, followed by an assessment of its psychometric properties, called local validation.

\section{OBJECTIVE}

The objective of this study was to describe the cross-cultural adaptation of the TRAQ to Argentinian Spanish.

\section{DEVELOPMENT \\ Instrument description}

The TRAQ 5.0 is targeted at patients aged 14 to 26 , and is made up of 20 items divided into 5 domains: Managing Medications, Appointment Keeping, Tracking Health Issues, Talking with Providers, and Managing Daily Activities. Each item has 5 response options which are scored 1 to 5: 1 is equivalent to minimum autonomy and 5, to maximum autonomy (see Annex 1).

\section{Population}

Professionals involved in the process were a certified translator, two bilingual physicians living in Argentina, a bilingual physician living in the USA, and an expert panel (a pediatric rheumatologist, an adult rheumatologist, two adolescent health specialists, and a fellow in pediatric rheumatology), who agreed upon and decided on the final version.

Participating patients were children and adolescents aged 14 to 21 who had chronic diseases, without cognitive impairment, and who were seen at the outpatient office of the Department of Pediatrics of Hospital Italiano de Buenos Aires. This is a community, tertiary care, general hospital. The Department of Pediatrics has 150 hospitalization beds, provides care in all pediatric specialties, and receives approximately 162000 patients every year at the Pediatrics and Adolescence outpatient offices. The prevalence of chronic diseases is approximately $20 \%$, and the hospital offers an institutional transition program for patients with this type of conditions.

Patients from Hospital Nacional de Pediatría Prof. Dr. J. P. Garrahan were included in the last field test. This is a national, public, referral hospital that provides pediatric tertiary care and sees a large number of children and adolescents with complex and/or chronic diseases from all Argentina. Given that this is a public facility, the population seen here is widely heterogeneous in terms of socioeconomic and education level.

Hospital Garrahan offers diverse transitiontransfer strategies at the different departments; however, given that this is a pediatric facility, unlike Hospital Italiano, all patients have to be transferred to other adult follow-up centers, mostly public hospitals given that patients usually lack private health coverage.

Participating patients gave their oral assent, and consent was given by their families. The protocol was approved by the Research and Ethics Committee of both hospitals.

\section{Strategy}

The method used for the cross-cultural adaptation of the questionnaire was that established by Beaton et al., 7 which includes the following steps: translation, first unified version, 1 to 3 back-translations, second unified version, field test in the target population, third unified version.

The entire process took place at Hospital Italiano. Once the third unified version was obtained, it was re-tested in the population from Hospital J. P. Garrahan.

The study was conducted in the period between July 2012 and December 2014.

\section{ADAPTATION PROCESS}

The following stages, summarized in Table 1, were conducted based on the process recommended for the cross-cultural adaptation of health questionnaires.

\section{Stage 0}

We contacted the TRAQ 5.0 authors (David Wood and Gregory Sawicki) to obtain their consent for the cross-cultural adaptation. 


\section{Stage 1}

The forward translation of the questionnaire was performed by two translators: one was a certified translator experienced in health care; the other was a bilingual pediatric resident. Focus was placed on the fact that semantic and conceptual aspects should have priority over linguistics.

\section{Stage 2}

Based on both translated versions, the research team and the expert panel held 7 meetings to review, discuss, and agree upon the header, the 20 items, and the response options so as to have the first version (version 1). The main change in the forward translation was that of replacing the formal Spanish "usted" with the informal "vos" (both "you" in English) in all questions.

\section{Stage 3}

Two back-translations were performed: one by a bilingual pediatric resident with experience in chronic conditions working at the Montefiore
Medical Center in New York, USA; the other by a bilingual rheumatologist living in Argentina.

\section{Stages 4 and 5}

Both back-translated versions were compared, and the Spanish version was adapted to ensure correspondence with the original. The research team and the expert panel coordinated any adjustment necessary during this stage. Once the following changes were introduced, the second version was agreed upon.

The original translation of question 1 "Do you fill a prescription if you need to?" was the only one that was modified several times based on cultural differences in how prescriptions are filled in our setting. Thus, the first translation was backtranslated as "Do you pick up your medication at the pharmacy when you need it?" and was finally agreed to be "Do you go to the pharmacy to get your medications when you need them?"

The original questionnaire authors were contacted again, and they grouped questions into 5 domains. Subheads were added in each

TABLE 1. Stages for the cross-cultural adaptation of the Transition Readiness Assessment Questionnaire 5.0, based on the recommendations by Beaton et al. ${ }^{5}$

\begin{tabular}{|c|l|l|}
\hline Stages & \multicolumn{1}{|c|}{ Steps } & \multicolumn{1}{|c|}{ Activity } \\
\hline Stage 0 & $\begin{array}{l}\text { Communication with the original } \\
\text { authors of the TRAQ 5.0. }\end{array}$ & $\begin{array}{l}\text { Authors were contacted on the telephone, via Skype } \\
\text { and e-mail. }\end{array}$ \\
\hline Stage 1 & $\begin{array}{l}\text { Two independent translators } \\
\text { performed the translation. }\end{array}$ & $\begin{array}{l}\text { One was a certified translator experienced in health care; } \\
\text { the other was a bilingual pediatric resident. }\end{array}$ \\
\hline Stage 2 & $\begin{array}{l}\text { Summary of the translation by } \\
\text { the expert review committee } \\
\text { (version 1). }\end{array}$ & $\begin{array}{l}\text { Seven meetings were held with the expert panel to solve } \\
\text { discrepancies until version 1 was obtained. }\end{array}$ \\
\hline Stage 3 & $\begin{array}{l}\text { Two independent translators } \\
\text { performed the back-translation. }\end{array}$ & $\begin{array}{l}\text { One was a bilingual pediatrician working in the USA; the } \\
\text { other was a bilingual rheumatologist working in Argentina. }\end{array}$ \\
\hline Stage 4 & $\begin{array}{l}\text { Expert review committee. } \\
\text { Stage 5 }\end{array}$ & $\begin{array}{l}\text { Both back-translations were compared and a single English } \\
\text { version was established, which was accepted by authors. }\end{array}$ \\
\hline Stage 6 & $\begin{array}{l}\text { Pre-testing (field test). } \\
\text { Stage 7 }\end{array}$ & $\begin{array}{l}\text { Femantic, idiomatic, and conceptual equivalents were } \\
\text { postablished, and version 2 was agreed upon. }\end{array}$ \\
\hline the Hospital Garrahan team.
\end{tabular}

TRAQ 5.0: Transition Readiness Assessment Questionnaire 5.0. 
domain, and version 2 was obtained and sent to the authors, who approved it.

\section{Stage 6}

A field test was done (pre-test) to establish if vocabulary was adequate and items were culturally applicable by means of individual interviews, and the target population's feedback was obtained, considering the different age ranges, level of education and/or disease severity. The coordinators of chronic disease programs (rheumatologists, nephrologists, gastroenterologists, hepatologists, diabetologists, and endocrinologists) organized 17 interviews to assess item comprehension. Based on their feedback, small changes were made in the questionnaire to decide on the third version (version 3).

The original questionnaire authors were contacted again and it was decided to review item 2 "Do you know what to do if you are having an adverse reaction to your medications?" to ensure that participants understood the meaning of "adverse reaction." For this reason, a new questionnaire comprehension test was planned in 10-year-old children attending $5^{\text {th }}$ grade of primary school, which was the comprehension level required for the original questionnaire development. Ten surveys were administered to children without chronic diseases

TABLE 2. Items modified for the final version of the Transition Readiness Assessment Questionnaire, Argentinian Spanish version

\begin{tabular}{|l|l|}
\hline \multicolumn{2}{|c|}{ Directions to parents/caregivers } \\
\hline \multicolumn{1}{|c|}{ Original item/domain } & \multicolumn{1}{|c|}{ New version } \\
\hline $\begin{array}{l}\text { If your youth is unable to complete the tasks below } \\
\text { on their own, please check the box that best } \\
\text { describes your skill level. }\end{array}$ & $\begin{array}{l}\text { If the youth you are taking care of is unable to } \\
\text { understand the meaning of the questions below on } \\
\text { his/her own, please answer them together and check } \\
\text { the box that best describes your youth's skill level. }\end{array}$ \\
\hline $\begin{array}{l}\text { Domain: Managing medications. } \\
\text { Question 1. Do you go to the pharmacy to get your } \\
\text { medications when you need them? }\end{array}$ & $\begin{array}{l}\text { When you need your medications, do you go to the } \\
\text { or are taking medication) }\end{array}$ \\
\hline $\begin{array}{l}\text { Question 2. Do you know what to do if you are } \\
\text { having an adverse reaction to your medications? }\end{array}$ & $\begin{array}{l}\text { Do you know what to do if you are having an adverse } \\
\text { reaction to your medications (for example: allergic } \\
\text { reaction, diarrhea due to medication)? }\end{array}$ \\
\hline $\begin{array}{l}\text { Question 5. Do you call the doctor's office to make } \\
\text { an appointment? }\end{array}$ & $\begin{array}{l}\text { Do you call the doctor's office to make an } \\
\text { appointment on your own? }\end{array}$ \\
\hline $\begin{array}{l}\text { Question 8. Do you call the doctor about unusual } \\
\text { changes in your health (for example: allergic } \\
\text { reactions, etc.)? }\end{array}$ & $\begin{array}{l}\text { Do you call the doctor about unusual changes in your } \\
\text { health on your own (for example: allergic reactions, etc.)? }\end{array}$ \\
\hline $\begin{array}{l}\text { Question 12. Do you fill out the medical history } \\
\text { form, including a list of your allergies? }\end{array}$ & $\begin{array}{l}\text { Are you capable of filling out the medical history form, } \\
\text { including a list of your allergies? }\end{array}$ \\
\hline $\begin{array}{l}\text { Question 13. Do you keep a calendar of medical } \\
\text { and other appointments? }\end{array}$ & $\begin{array}{l}\text { Do you record your medical and other appointments } \\
\text { in any way (calendar, list, mobile phone, etc.)? }\end{array}$ \\
\hline $\begin{array}{l}\text { Question 15. Do you get financial help from any } \\
\text { institution? }\end{array}$ & $\begin{array}{l}\text { Do you get financial help from any institution (social } \\
\text { benefit, pension, financial support, etc.)? }\end{array}$ \\
\hline
\end{tabular}


who had attended the hospital for a check-up; none demonstrated comprehension problems, so version 3 was not modified. The original questionnaire version from 2012 did not include directions to parents or caregivers on how to fill in the questionnaire if their youth was not capable to do so. The group in charge of developing the questionnaire added, in the 2014 version, a paragraph to this end, which was also included in the translation (see Annex 2): "Directions to Parents/Caregivers: If the youth you are taking care of is unable to understand the meaning of the questions below on his/her own, please answer them together and check the box that best describes your youth's skill level. Check here if you are a parent/caregiver completing this form."

\section{Stage 7}

Finally, during the last stage, and working together with the research team from Hospital Garrahan, a field test was performed for questionnaire validation in 5 patients older than 16 years old from each hospital. Some items / domains were modified because comprehension difficulties were observed. Changes are detailed in Table 2 and were agreed upon by all research team members. Modifications proved effective because such difficulties were resolved in the subsequent step of the validation process.

\section{DISCUSSION}

This study describes the cultural adaptation process of an instrument used to measure the readiness of patients to shift from pediatric into adult care targeted at adolescents with chronic diseases.

This is the first stage of the process to have the Argentinian version of the TRAQ 5.0 available for use by different groups of patients in our country, either for research or health care purposes. To our knowledge, this questionnaire is being adapted in other countries, e.g., Mexico and Brazil (personal communication), but results have not been published yet.

The methodology was based on international recommendations $\mathrm{s}^{7-10}$ to obtain a version that is culturally adequate for the local population and semantically equivalent to the original version. This is why the final version was obtained only after various stages.

The domains assessed in the questionnaire refer to autonomy and self-care, and although it is a general instrument that is not specific for any group of patients with a particular disease, in our sample we did not include patients with major cognitive impairment, even though the original authors had included a small number of these patients in their study.

Regarding the level of question comprehension, although the TRAQ is targeted at a population aged 14 to 26 , the original authors, in communication with the local research team, recommended checking the level of semantic comprehension in children who had completed $5^{\text {th }}$ grade of primary school; for this reason, the pre-test was performed in this age group.

Any cross-cultural adaptation of a questionnaire ${ }^{6}$ may pose the limitation of leaving out specific aspects of different local populations, e.g., population sectors attending the private versus the public health care systems. To prevent such limitation, our sample included Hospital Juan P. Garrahan in the last stage of the adaptation process.

Now that the Argentinian Spanish version has been obtained, it is necessary to re-assess its psychometric properties and implementation feasibility in our population, which is the objective of a subsequent study to determine questionnaire validity.

The resulting questionnaire to assess transition readiness has been translated and adapted to the Argentinian population and will be useful in health care and research settings, and will allow its comparison with different populations from Argentina and other countries. It will also serve to assess the performance of different transition programs in our setting.

\section{CONCLUSION}

The TRAQ 5.0 has been translated and crossculturally adapted to be used in the Argentinian population aged 14 to 26 in compliance with the international recommendations for this process.

\section{Acknowledgments}

We would like to thank patients, their families, Luis Catoggio, M.D., Nora Esteban, M.D., Arabella T. Sota, M.D., Ángela Gilardoni, B.S., and Florencia de la Torre, B.S. We would also like to thank the authors of the original questionnaire: David Wood, M.D., and Gregory Sawicki, M.D., for their support and collaboration throughout the translation and adaptation process.

\section{REFERENCES}

1. White PH. Transition: a future promise for children and adolescents with special health care needs and disabilities. Rheum Dis Clin North Am 2002;28(3):687-703. 
2. Zhang LF, Ho JS, Kennedy SE. A systematic review of the psychometric properties of transition readiness assessment tools in adolescents with chronic disease. BMC Pediatr 2014;14:4.

3. Wood DL, SawickiGS, Miller MD,Smotherman C, etal. The Transition Readiness Assessment Questionnaire (TRAQ): its factor structure, reliability, and validity. Acad Pediatr 2014;14(4):415-22.

4. Sawicki GS, Lukens-Bull K, Yin X, Demars N, et al. Measuring the transition readiness of youth with special healthcare needs: validation of the TRAQ-Transition Readiness Assessment Questionnaire. J Pediatr Psychol 2011;36(2):160-71.

5. Prochaska JO,DiClementeCC. The transtheorical approach. In Norcross JC, ed. Handbook of eclectic psychotherapy. New York: Brunner/Mazel;1986:163-200.

6. Berra S, Bustingorry V, Henze C, Díaz M, et al. Adaptación transculturaldelcuestionarioKIDSCREEN paramedircalidad de vida relacionada con la salud en población argentina de 8 a 18 años. Arch Argent Pediatr 2009;107(4):307-14.

7. Beaton DE, Bombardier C, Guillemin F, Ferraz MB. Guidelines for the process of cross-cultural adaptation of self report measures. Spine (phila Pa 1976) 2000;25(24):318691.

8. Badía X. Sobre la adaptación transcultural de medidas de calidad de vida relacionada con la salud para su uso en España. Med Clin (Barc) 1995;105:56-8.

9. Wild D, Grove A, Martin M, Eremenco S, et al. ISPOR Task Force for Translation and Cultural Adaptation. Principles of Good Practice for the Translation and Cultural Adaptation Process for Patient-Reported Outcomes (PRO) Measures: report of the ISPOR Task Force for Translation and Cultural Adaptation. Value Health 2005;8(2):94-104.

10. Guillemin F, Bombardier C, Beaton D. Cross-cultural adaptation of health-related quality of life measures: literature review and proposed guidelines. JClin Epidemiol 
ANNEx 1. Transition Readiness Assessment Questionnaire 5.0, original version

Patient Name:

Date of Birth:

. Today's Date:

(MRN\#

).

\section{Transition Readiness Assessment Questionnaire}

Directions: Please check the box that best describes your skill level in the following areas that are important for transition to adult health care. There is no right or wrong answer and your answers will remain confidential and private.

\begin{tabular}{|c|c|c|c|c|c|}
\hline & $\begin{array}{c}\text { No, } \\
\text { I do not } \\
\text { know how } \\
\text { (1) }\end{array}$ & $\begin{array}{c}\text { No, } \\
\text { but I want } \\
\text { to learn } \\
\text { (2) }\end{array}$ & $\begin{array}{l}\text { I am } \\
\text { learning } \\
\text { to do } \\
\text { this } \\
\text { (3) }\end{array}$ & $\begin{array}{c}\text { Yes, } \\
\text { I have } \\
\text { started } \\
\text { doing this } \\
\text { (4) }\end{array}$ & $\begin{array}{c}\text { Yes, } \\
\text { I always do } \\
\text { this when I } \\
\text { need to } \\
\text { (5) }\end{array}$ \\
\hline \multicolumn{6}{|l|}{ Managing Medications } \\
\hline \multicolumn{6}{|l|}{ Do you fill a prescription if you need to? } \\
\hline \multicolumn{6}{|l|}{$\begin{array}{l}\text { Do you know what to do if you are having a bad reaction to } \\
\text { your medications? }\end{array}$} \\
\hline \multicolumn{6}{|l|}{ Do you take medications correctly and on your own? } \\
\hline \multicolumn{6}{|l|}{ Do you reorder medications before they run out? } \\
\hline \multicolumn{6}{|l|}{ Appointment Keeping } \\
\hline \multicolumn{6}{|l|}{ Do you call the doctor's office to make an appointment? } \\
\hline \multicolumn{6}{|l|}{$\begin{array}{l}\text { Do you follow-up on any referral for tests or check-ups or } \\
\text { labs? }\end{array}$} \\
\hline \multicolumn{6}{|l|}{ Do you arrange for your ride to medical appointments? } \\
\hline \multicolumn{6}{|l|}{$\begin{array}{l}\text { Do you call the doctor about unusual changes in your } \\
\text { health (for example: allergic reactions)? }\end{array}$} \\
\hline \multicolumn{6}{|l|}{$\begin{array}{l}\text { Do you apply for health insurance if you lose your current } \\
\text { coverage? }\end{array}$} \\
\hline \multicolumn{6}{|l|}{ Do you know what your health insurance covers? } \\
\hline \multicolumn{6}{|l|}{$\begin{array}{l}\text { Do you manage your money \& budget household } \\
\text { expenses (for example: use checking/debit card)? }\end{array}$} \\
\hline \multicolumn{6}{|l|}{ Tracking Health Issues } \\
\hline \multicolumn{6}{|l|}{$\begin{array}{l}\text { Do you fill out the medical history form, including a list of } \\
\text { your allergies? }\end{array}$} \\
\hline \multicolumn{6}{|l|}{$\begin{array}{l}\text { Do you keep a calendar or list of medical and other } \\
\text { appointments? }\end{array}$} \\
\hline \multicolumn{6}{|l|}{ Do you make a list of questions before the doctor's visit? } \\
\hline \multicolumn{6}{|l|}{ Do you get financial help with school or work? } \\
\hline \multicolumn{6}{|l|}{ Talking with Providers } \\
\hline \multicolumn{6}{|l|}{ Do you tell the doctor or nurse what you are feeling? } \\
\hline \multicolumn{6}{|l|}{$\begin{array}{l}\text { Do you answer questions that are asked by the doctor, } \\
\text { nurse, or clinic staff? }\end{array}$} \\
\hline \multicolumn{6}{|l|}{ Managing Daily Activities } \\
\hline \multicolumn{6}{|l|}{ Do you help plan or prepare meals/food? } \\
\hline \multicolumn{6}{|l|}{ Do you keep home/room clean or clean-up after meals? } \\
\hline $\begin{array}{l}\text { Do you use neighborhood stores and services (for } \\
\text { example: grocery stores and pharmacy stores)? }\end{array}$ & & & & & \\
\hline
\end{tabular}

(c) Wood, Sawicki, Reiss \& Livingood, 2012. 
ANNEx 2. Transition Readiness Assessment Questionnaire 5.0, back-translation of the final version in Argentinian Spanish

\section{Patient Name:}

Date of Birth:

1
Today's Date:

Directions to Youth: Please check the box that best describes your skill level in the following areas that are important for transition to adult health care. There is no right or wrong answer and your answers will remain confidential and private.

Directions to Parents/Caregivers: If the youth you are taking care of is unable to understand the meaning of the questions below on his/her own, please answer them together and check the box that best describes your youth's skill level.

Check here if you are a parent/caregiver completing this form.

\begin{tabular}{|l|l|l|l|l|l|}
\hline & $\begin{array}{c}\text { No, I do not } \\
\text { know how }\end{array}$ & $\begin{array}{c}\text { No, but I } \\
\text { want to } \\
\text { learn }\end{array}$ & $\begin{array}{c}\text { No, but I am } \\
\text { learning to } \\
\text { do this }\end{array}$ & $\begin{array}{c}\text { Yes, I have } \\
\text { started } \\
\text { doing this }\end{array}$ & $\begin{array}{c}\text { Yes, I always } \\
\text { do this when } \\
\text { I need to }\end{array}$ \\
\hline $\begin{array}{l}\text { Managing Medications (for patients who have } \\
\text { taken or are taking medication) }\end{array}$ & & & & & \\
\hline $\begin{array}{l}\text { 1. When you need your medications, do you go } \\
\text { to the pharmacy to get them? }\end{array}$ & & & & & \\
\hline $\begin{array}{l}\text { 2. Do you know what to do if you are having an } \\
\text { adverse reaction to your medications (for } \\
\text { example: allergic reaction, diarrhea due to } \\
\text { medication)? }\end{array}$ & & & & & \\
\hline $\begin{array}{l}\text { 3. Do you take your medications correctly and } \\
\text { on your own? }\end{array}$ & & & & & \\
\hline $\begin{array}{l}\text { 4. Do you reorder your medications before they } \\
\text { run out? }\end{array}$ & & & & & \\
\hline Appointment Keeping & & & & \\
\hline $\begin{array}{l}\text { 5. Do you call the doctor's office to make an } \\
\text { appointment on your own? }\end{array}$ & & & & & \\
\hline $\begin{array}{l}\text { 6. Do you keep track of specialist referrals, } \\
\text { check-ups or laboratory test results? }\end{array}$ & & & & & \\
\hline $\begin{array}{l}\text { 7. Do you arrange for your ride to your medical } \\
\text { appointments? }\end{array}$ & & & & & \\
\hline $\begin{array}{l}\text { 8. Do you call the doctor about unusual } \\
\text { changes in your health on your own (for } \\
\text { example: allergic reactions, etc.)? }\end{array}$ & & & & & \\
\hline $\begin{array}{l}\text { 9. Do you know how to apply for health } \\
\text { insurance if you lose your current coverage? }\end{array}$ & & & & & \\
\hline $\begin{array}{l}\text { 10. Do you know what benefits are covered by } \\
\text { your health insurance, HMO, etc.? }\end{array}$ & & & & \\
\hline $\begin{array}{l}\text { 11. Do you manage your own money and pay } \\
\text { for your household expenses (for example: use } \\
\text { debit card, credit card, etc.)? }\end{array}$ & & & & & \\
\hline
\end{tabular}




\begin{tabular}{|l|l|l|l|l|l|}
\hline Tracking Health Issues & & & & \\
\hline $\begin{array}{l}\text { 12. Are you capable of filling out the medical } \\
\text { history form, including a list of your allergies? }\end{array}$ & & & & & \\
\hline $\begin{array}{l}\text { 13. Do you record your medical and other } \\
\text { appointments in any way (calendar, list, mobile } \\
\text { phone, etc.)? }\end{array}$ & & & & & \\
\hline $\begin{array}{l}\text { 14. Do you make a list of questions before you } \\
\text { go to your doctor's visit? }\end{array}$ & & & & & \\
\hline $\begin{array}{l}\text { 15. Do you get financial help from any } \\
\text { institution (social benefit, pension, financial } \\
\text { support, etc.)? }\end{array}$ & & & & & \\
\hline Talking with Providers & & & & & \\
\hline $\begin{array}{l}\text { 16. Do you tell your doctor or nurse about what } \\
\text { you are feeling? }\end{array}$ & & & & & \\
\hline $\begin{array}{l}\text { 17. Do you answer the questions asked by the } \\
\text { doctor, nurse, or health team staff? }\end{array}$ & & & & & \\
\hline Managing Daily Activities & & & & & \\
\hline $\begin{array}{l}\text { 18. Do you help plan or prepare meals? } \\
\text { 19. Do you keep your room/home clean and/or } \\
\text { clear the table and/or do the dishes after meals? }\end{array}$ & & & & & \\
\hline $\begin{array}{l}\text { 20. Do you use neighborhood stores (for } \\
\text { example: grocery stores, pharmacy stores, etc.)? }\end{array}$ & & & & & \\
\hline
\end{tabular}

